University of Nebraska - Lincoln

DigitalCommons@University of Nebraska - Lincoln

USDA National Wildlife Research Center - Staff Publications
U.S. Department of Agriculture: Animal and Plant Health Inspection Service

July 2003

\title{
LETHAL CONTROL OF RED-WINGED BLACKBIRDS TO MANAGE DAMAGE TO SUNFLOWER: AN ECONOMIC EVALUATION
}

\author{
Bradley F. Blackwell \\ USDA/APHIS/WS National Wildlife Research Center, bradley.f.blackwell@aphis.usda.gov \\ Eric Huszar \\ U.S. Department of Agrrculture, Animal and Plant Health Inspectron Service, Policy and Program \\ Development, Polrcy Analysrs and Development
}

George M. Linz

USDA/APHIS/WS National Wildlife Research Center, george_m_linz@yahoo.com

Richard A. Dolbeer

U.S. Department of Agriculture, Animal and Plant Health Inspection Servrce, National Wildlife Research Center, Ohro Field Station

Follow this and additional works at: https://digitalcommons.unl.edu/icwdm_usdanwrc

Part of the Environmental Sciences Commons

Blackwell, Bradley F.; Huszar, Eric; Linz, George M.; and Dolbeer, Richard A., "LETHAL CONTROL OF REDWINGED BLACKBIRDS TO MANAGE DAMAGE TO SUNFLOWER: AN ECONOMIC EVALUATION" (2003). USDA National Wildlife Research Center - Staff Publications. 223.

https://digitalcommons.unl.edu/icwdm_usdanwrc/223

This Article is brought to you for free and open access by the U.S. Department of Agriculture: Animal and Plant Health Inspection Service at DigitalCommons@University of Nebraska - Lincoln. It has been accepted for inclusion in USDA National Wildlife Research Center - Staff Publications by an authorized administrator of DigitalCommons@University of Nebraska - Lincoln. 


\title{
LETHAL CONTROL OF RED-WINGED BLACKBIRDS TO MANAGE DAMAGE TO SUNFLOWER: AN ECONOMIC EVALUATION
}

\author{
BRADLEY F. BLACKWELL, ${ }^{1}$ U.S. Department of Agriculture, Animal and Plant Health Inspection Service, National Wildlife \\ Research Center, Ohio Field Station, 6100 Columbus Avenue, Sandusky, OH 44870, USA \\ ERIC HUSZAR, U.S. Department of Agriculture, Animal and Plant Health Inspection Service, Policy and Program Development \\ Policy Analysis and Development, 4700 River Road, Riverdale, MD 20737-1238, USA \\ GEORGE M. LINZ, U.S. Department of Agriculture, Animal and Plant Health Inspection Service, National Wildlife Research Cen- \\ ter, Great Plains Field Station, 2110 Miriam Circle, Bismarck, ND 58501-2502, USA \\ RICHARD A. DOLBEER, U.S. Department of Agriculture, Animal and Plant Health Inspection Service, National Wildife Research \\ Center, Ohio Field Station, 6100 Columbus Avenue, Sandusky, OH 44870, USA
}

\begin{abstract}
In the northem Great Plains of the United States, conflicts between red-winged blackbirds (Agelaius phoenireus) and sunflower (Helianthus anmus) growers have intensified since the late 1960s due to the expanded commercial production of sunflowers. We studied the potential population effects of the removal of up to 2 million red-winged blackbirds annually under a 5-year program of baiting during spring with DRC-1339 (3-choloro-4 mothalalanine)-treated rice. We also examined whether lethal control, in combination with current levels of breed ing-habitat management, would be cost-effective in decreasing depredation of sunflower crops during late summer. We cvaluated the cost-benefit ratio for 4 culling scenarios involving (1) variable annual culls, not excecding $2 \mathrm{mil}-$ lion birds, with and without density compensation (i.e., a positive density-dependent response) on adult survival; and (2) culls of 2 million birds annually with and without density compensation. We constructed a red-winged blackbird population model represented as an age-based matrix and calibrated to stable growth. We assumed a total population of 27 million birds on 1 April (week 1), representing the red-winged blackbird breeding population staging in eastern South Dakota and migrating into North Dakota. Under each culling scenario, we reduced the stable redwinged blackbird population (equally for females and males) and projected the population through week 23 of the annual cycle ( $2 \mathrm{Sep}$ ). We then evaluated the associated costs of the management relative to potential sunflower crop losses, assuming $\$ 0.07$ in damage per bird and $4 \%$ loss to other factors. Variable annual culls, likely the more biologically realistic model scenarios, yielded mean annual removals of $1,240,560(\mathrm{SE}=12,328)$ birds with density compensation and $1,231,620(\mathrm{SE}=28,811)$ birds without density compensation, with cost-benefit ratios of $1: 2.3$ and 1:3.6, respectively. Annual intrinsic rates for the model population over the 5-year period ranged from $-1.4 \mathrm{to}$ $-4.8 \%$. Considering potential variability in the effectiveness of the cull and the combination of direct and indirect costs, we contend that the realized benefits to sunflower growers by lethal control of red-winged blackbircls via spring baiting, in combination with current nonlethal management efforts, would likely be negligible.
\end{abstract}

JOURNAL OF WILDLIFE MANAGEMENT 67(4):818-828

Key words: Agetrius phoniumes, DRC-1339, economic, Helianthus ammus, lethal control, matrix model, population demographics, red-winged blackbird, sunflower.

Sunflowers are native to North America and have becn cultivated as a commercial crop in the Great Plains since the late 1960s (L inz and Hanzel 1997). Approximately $73 \%$ of the 1.95 billion $\mathrm{kg}$ of sunflower produced in the United States is grown in South Dakota and North Dakota (National Agricultural Statistics Service [NASS] 1999) and represents $>809,400$ production ha (NASS 2000 ). In 2000, growers in North Dakota harvested over 509,922 ha of sunflower, valued at $\$ 125$ million. Growers in South Dakota harvested 282,885 ha valued at $\$ 63$ million (NASS 2000). Although representing on average only $8 \%$ of the total $\$ 2$ billion in agricultural production annually across the 2 states, the combination of sunflower pro-

${ }^{1}$ E-mail: bradley fblackwell@aphis.usda.gov duction and processing industries supports a regional economy worth $>\$ 906$ million annually (Bangsund and Leistritz 1995).

Concurrent with the growth of the sunflower industry in the Great Plains have been increased conflicts associated with bird (primarily redwinged blackbird; hereafter referred to as redwing) depredation of unharvested crops in late summer (Linz et al. 1984, Linz and Hanzel 1997). Although North American Breeding Bird Survey (BBS) data indicate an overall decline in redwinged blackbird populations survey-wide $(\bar{x}$ change $/ y$ in birds per route $=-1.0 \% ; n=3,420$; $P<0.01$; 1966-2000), populations in South Dakota and North Dakota have been relatively stable over the 35-year period ( $\bar{x}$ change/yr in birds per route, South Dakota $=0.2 \%, n=46, P=0.78$; North Dakota $=0.4 \%, n=47, P=0.60)$. However, 
red-wing populations in these 2 states have shown moderate growth over the last decade (Sauer et al. 2001). Peer et al. (2003) estimated annual losses to red-wing depredation at $\$ 2.8$ million, approximately $0.9 \%$ of the $\$ 315$ million in sunflower seed harvested in 1999 (U.S. Department of Agriculture [USDA] 2000). Although overall damage by red-wings is minimal, damage is distributed unevenly across sunflower producers (Hothem et al. 1988) depending on crop rotations and proximity of plantings to wetland roosts (Leitch et al. 1997). For example, in 276 fields surveyed in Stutsman County, North Dakota (1994-1998), 47 fields received damage in excess of $5 \%$ and 22 fields received damage exceeding $10 \%$ (NASS 1999). Profit margins (i.e., planting and harvest costs vs. income) are considered negligible at best when damage exceeds $10 \%$, and fields with $>70 \%$ damage are considered total losses (National Sunflower Association, unpublished data).

Under direction of the U.S. Congress, the USDA Wildlife Services (WS) program solicited public comment on a scoping document for an Environmental Impact Statement (EIS) to evaluate potential environmental effects of managing blackbirds (Icteridae) to protect unharvested sunflower in the Dakotas (USDA 2001). One scenario would involve an integrated adaptive management program that includes nonlethal methods of reducing damage to sunflower crops in combination with a culling effort. The primary nonlethal management option would comprise an increase in herbicide treatments of cattail (Typha latifolia, T. angustifolia, T. glauca)-dominated wetlands from 2,428 ha to 3,238 ha annually (i.e., increasing treatment from 0.8 to $1.1 \%$ of total cattail area), thus treating approximately $5 \%$ of cattail-dominated wetlands during a 5-year program (USDA 2001).

Competitive exclusion of wetland flora by cattail (largely $T$. angustifolia [exotic], and T. glauca [hybrid of native T. latifolia and T. angustifolia]) and the subsequent decrease in area of open water is positively correlated with breeding populations of red-wings, but also yellow-headed blackbirds (Xanthocephalus xanthocephalus) and marsh wrens (Cistothorus palustris; Linz et al. 1996a; see also Homan et al. 2003). However, high cattail density also contributes to a decrease in the diversity and abundance of wetland-dwelling birds (Kantrud 1986). Species such as the black tern (Chlidonias niger), northern pintail (Anas acuta), mallard (A. platyrhnchos), and American coot (Fulica americana) have responded positively to cattail reduction efforts (Linz et al. 1994, 1996b, 1997; Linz and Blixt 1997). Further, herbicide programs that are staggered on wetland complexes can help maintain wetland bird diversity and abundance by providing various stages of cattail decomposition and regeneration, as well creating a mosaic of open water and vegetation (Linz et al. 1996a, 1997).

Concurrent with the herbicide program would be a 5-year lethal control program via spring baiting with DRC-1339 (3-choloro-4-methylalanine)treated rice $(0.02 \mathrm{~g} / \mathrm{g}$ rice $)$ to remove up to $2 \mathrm{mil}-$ lion red-wings annually. The baiting program would comprise up to 250.8 -ha plots annually in harvested grain fields near blackbird (predominantly red-wing) staging areas in South Dakota. Baiting areas would be designated based on the most current data on red-wing roost-site distribution and would likely include Clark, Codington, Hamlin, Deuel, Kingsbury, Brookings, Miner, Lake, and Moody Counties in South Dakota (USDA 2001). Spring baiting with DRC-1339 also presents acute hazards to nontarget species such as the western meadowlark (Sturnella neglecta), mourning dove (Zenaida macroura), and ringnecked pheasant (Phasianus colchicus; Eisemann et al. 2001, Linz et al. 2002b). However, mitigation measures currently employed in the baiting program (e.g., targeting staging areas used predominantly by red-wings) minimize the hazards to nontarget species (Eisemann et al. 2001).

Data from color-marking studies of springmigrating red-wings at roosts in eastern South Dakota (Knittle et al. 1987, Homan et al. 2002) and northwestern Missouri (Knittle et al. 1987) indicate that birds from spring roosts in South Dakota compose the majority of red-wings breeding within or on the periphery of the sunflower growing region. In addition, morphometric analysis of ulnas from red-wings collected at spring roosts in eastern South Dakota and southwestern Minnesota also indicated that birds using spring roosts in South Dakota probably are the same birds breeding near the sunflower growing region (Linz et al. 1993). Further, Dolbeer (1978) suggested, based on analysis of band-recovery data, that red-wings that hatch locally (within 200 $\mathrm{km}$ ) are most likely responsible for depredation of ripening grain crops during the post-reproductive period. Besser et al. (1983) noted that southward migration of red-wings from North Dakota and South Dakota begins in early August, corresponding with ripening sunflower crops. Homan et al. (2002) found that $82 \%$ of red-wings 
Table 1. Age-classified ${ }^{a}$ projection matrix for the female component of a stable red-winged blackbird population. Fertility estimates (row 1) comprised the product of age-specific proportion of females breeding (assumed to be $100 \%$ ), mean number of female young fledged per female breeder ${ }^{b}$, and survival from fledging to just before age $1^{\mathrm{c}}$.

\begin{tabular}{lll}
\hline$F_{1}=0.21785$ & $F_{2}=0.43570$ & $F_{3}=0.54123$ \\
$S_{1}=0.61000$ & 0.00000 & 0.00000 \\
0.00000 & $S_{2}=0.61000$ & $S_{3}=0.61000$
\end{tabular}

${ }^{a} F_{\text {age }}$ values represent fertility of birds about to turn age 1 $\left(F_{1}\right)$, birds about to turn age $2\left(F_{2}\right)$, and birds about to turn age $3+\left(F_{3+}\right) ; S_{a g e}$ values represent survival of birds from just before age 1 to just before age $2\left(S_{1}\right)$, just before age 2 to just before age $3\left(S_{2}\right)$, and just before age 3 on $\left(S_{3+}\right)$.

bemale fledglings per age-1 female: 0.514 ; age-2 female: 1.028; age-3+ female: 1.277.

c Composite of juvenile survival to parental independence $(0.6948)$ and the equivalent annual survival of adults $(0.6100)$, as per Stehn 1989c.

colormarked in eastern South Dakota during spring migration fed on ripening sunflower during late summer.

However, manipulation of wildlife populations to mitigate damage or other conflicts should be preceded by an evaluation of the efficacy of the management method and potential effects on the target and nontarget populations. We evaluated the potential population effects of killing up to 2 million red-wings annually for up to 5 years and whether lethal control during spring, given current nonlethal management efforts (i.e., herbicide treatment of approximately $0.8 \%$ of cattaildominated wetlands annually), would be costeffective for reducing damage to sunflower crops during late summer. Our objectives were to (1) construct a red-wing population model, represented as an age-based matrix and calibrated to stable growth; (2) simulate potential population effects of 4 -year culling scenarios based on the maximum proposed removal, via spring baiting, of 2 million birds annually; and (3) estimate the cost-benefit ratios of the 4 culling scenarios.

\section{METHODS}

\section{Model Parameterization}

One sex cannot likely be considered as dominating or driving the population dynamics of the red-wing (see Caswell 1989). For example, withinseason annual rates of increase likely differ due to marked differences in male and female seasonal migration patterns (Dolbeer 1982). Further, differential demands on males and females within the polygynous mating system, along with probable differential adult survival (but see
Searcy and Yasukawa 1981), lead to an adult sex ratio that differs from unity. Nevertheless, data necessary to construct a biologically realistic 2 -sex model (Caswell 1989) for red-wings migrating through eastern South Dakota (and subsequently breeding in North Dakota) are few. Hence, we constructed a red-wing population model calibrated to stable growth, but with annual projections based on the contribution of parameters for females. By relying on demographic parameters for females in our model, we simplified assumptions regarding annual fertility effects resulting from culling scenarios.

\section{Matrix Construction and Calibration}

In constructing the matrix population model for red-wings, we followed methods described by Caswell (1989) and McDonald and Caswell (1993). We also adhered closely to the methods described by Blackwell et al. (2002) in their development of a matrix model for double-crested cormorants (Phalacrocorax auritus) on Lake Ontario. We constructed an age-classified matrix population model for female red-wings projected over the annual cycle and based on a prebreeding census (i.e., tracking the first age class from being almost age 1 at the beginning of Apr until almost age 2). We referenced unpublished (Stehn $1989 a, b, c)$ and published (Beletsky 1996) demographic data for red-wings across the United States and Canada, then calibrated our matrix relative to a stable red-wing population size (Table 1). The assumption of a prebreeding census allowed the effects of first-year mortality to be incorporated into the fertility coefficients (Caswell 1989).

We grouped birds into 3 age classes relative to the prebreeding census: age- $1=$ birds about to turn age 1 ; age- 2 = birds about to turn age 2 ; and age- $3+=$ birds about to turn age 3 and older. Although some evidence exists that female life expectancy is around 3 years (Beletsky 1996), we assumed that some birds would survive beyond age 3 . We note that by including all birds about to turn age 3 or older within the third age class, our model could be considered as a stage-classified model. A stage-classified model differs from an age-classified model in that a stage may comprise individuals differing in age, but sharing factors (e.g., breeding experience) known to affect vital rates (Caswell 1989, McDonald and Caswell 1993). However, the life expectancy for red-wings provides little justification for a stage classification. 
The resulting age-classified matrix,

$$
X=\left[\begin{array}{ccc}
F_{1} & F_{2} & F_{3+} \\
S_{1} & 0 & 0 \\
0 & S_{2} & S_{3+}
\end{array}\right],
$$

comprised fertility elements for birds about to turn age $1\left(F_{1}\right)$, birds about to turn age $2\left(F_{2}\right)$, and birds about to turn age $3+\left(F_{3+}\right)$ on the first row. Here, fertility was related to the age-specific proportion of females breeding $\left(P B_{\text {age }}\right)$, mean number of female young fledged per female $\left(F l_{\text {age }}\right)$, and survival of young from fledging to just before age $1\left(S_{0}\right)$ as

$$
F_{\text {age }}=P B_{\text {age }} F l_{\text {age }} S_{0} .
$$

We defined fecundity (i.e., $F l_{a g e}$ ) as the mean number of female young fledged per female. We assumed that $S_{0}$ comprised survival rate to parental independence (approx 3 weeks after fledging) and survival equivalent to adult survival for the balance of the year (as per Stehn $1989 \mathrm{c}$, Table 1). Subsequent rows of the projection matrix included survival of females from just before age 1 to just before age $2\left(S_{1}\right)$, just before age 2 to just before age $3\left(S_{2}\right)$, just before age 3 on $\left(S_{3+}\right)$. We assumed equivalent annual survival for adult males (see below for introduction of males into the model) and calibrated age- $3+$ fertility to achieve, for heuristic purposes, an intrinsic rate of $r=0$. The rate $r$ represents the exponential rate at which a population with a stable age distribution grows given unlimited resources (Caughley 1977).

We assumed a 1:1 sex ratio of adults and multiplied the population vector (see Caswell 1989, McDonald and Caswell 1993, Blackwell et al. 2002) at time $t$ by 0.5 to obtain the number of adult females breeding per age (assuming that all females would breed). We then multiplied the population vector at time $t+1$ by 2 (assuming a 1:1 sex ratio for offspring) to obtain the total postbreeding population size (Fig 1).

To evaluate the sensitivity of the finite rate of increase of a population $\left(\lambda_{X}\right.$, the dominant eigenvalue of $X$ ) and, therefore $r$, to effects on fertility and survival, both the stable age distribution $\left(\mathrm{W}_{X}\right.$, the right eigenvector of $\left.X\right)$ and the reproductive value $\left(V_{X}\right.$, the left eigenvector of $X$ ) are necessary (see Caswell 1989, McDonald and Caswell 1993). We used MATLAB (The Math Works, Inc., Natick, Massachusetts, USA) to cal-

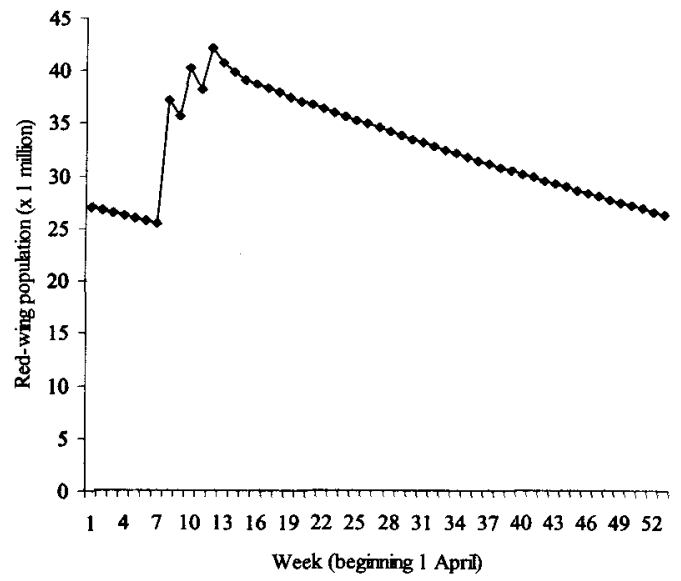

Fig. 1. Annual cycle of a stable $(r=0.0)$ red-winged blackbird population, assuming an initial population size of 27 million birds during the first week of April (model week 1), annual adult survival of 0.61 , a composite of juvenile survival that comprised survival to parental independence $(0.6948)$ and the equivalent annual survival of adults $(0.6100)$, a $1: 1$ sex ratio of adults and young, $100 \%$ of females breeding, 0.514 female fledglings per age- 1 female, 1.028 female fledglings per age-2 female, and 1.277 female fledglings per age- $3+$ female, fledgling production by age- $3+$ females by week 8 ( 20 May), age-2 females by week 10 ( 3 Jun), and age-1 females by week 12 (17 Jun). Annual survival is expressed as a weekly probability. Fledgling production (which can extend through late Jun) is evidenced by the sharp increase in bird numbers beginning at week 8 .

culate $\lambda_{X}$, corresponding eigenvectors, and simulate culling scenarios.

\section{Elasticity of $\lambda_{X}$}

We calculated the proportional change in $\lambda_{X}$ relative to proportional changes in the elements $x_{i j}$ of the projection matrix $X$ (i.e., the elasticity). Elasticity measures the effect of a change in the transition element $x_{i j}$ (e.g., age-specific fertility or survival) on the population growth rate $\lambda_{X}$, relative to the effects of equal and absolute changes in other elements (Caswell et al. 1984, de Kroon et al. 1986). Also, elasticity measures for matrix elements provide useful information for managing populations of interest. For example, elasticity measures can be used to identify potential management strategies that might either lead to the fastest rate of population recovery (Beissinger and Westphal 1998), or to efficient reduction in population growth of "nuisance" species. The elasticity of $\lambda_{X}$ is represented as

$$
\frac{x_{i j}}{\lambda_{x}}\left(\frac{v_{i} w_{j}}{\left\langle V_{x}, W t\right\rangle}\right),
$$


where $v_{i}$ is the $i^{\text {th }}$ element of $V_{X}, w_{j}$ is the $j^{\text {th }}$ element of $W_{X}$, and \langle\rangle indicates the scalar product of the vectors $V_{X}$ and $W_{X}$ (Caswell et al. 1984; see also Caswell 1989).

\section{Culling Simulations}

We evaluated effects of 4 increasingly progressive 5-year culling scenarios (removing equivalent age-specific numbers of males and females) and assumed an initial population of 27 million redwings prior to the first cull of each scenario (see Peer et al. 2003). Also, we assumed that culling would occur immediately prior to the breeding season (i.e., surviving birds would breed subsequent to the cull) and that the resulting removals would be added to mortality that had already occurred during the preceding annual cycle. For each of the 4 scenarios, we also assumed no compensatory response on fertility; positive reproductive compensation in response to decreased competition likely would be affected by loss of breeding habitat due to concurrent treatment of cattaildominated wetlands with herbicide. We note, however, that the complexity of the response of agespecific breeding dynamics (e.g., harem size and young fledged per breeding female) to increased herbicide treatment of cattail-dominated wetlands exceeds that of this deterministic approach.

Scenario I: Median Variable Annual Cull and Density Compensation.-For our first scenario, we assumed that the total cull could approach, but not exceed 2 million birds. Within each cull year, we generated a random, age-specific percentage to be removed for each of 1,000 permutations. From the 1,000 permutations within a year, we calculated the median age-specific percentage to be removed, and this median percentage reflected the cull for that year.

We assigned age-specific removals for the first cull year based on the stable age distribution $W_{X}$, and randomly reduced the prebreeding population by (a) $5.00-9.50 \%$ for age- 1 birds, reflecting a maximum loss of 1 million individuals; and (b) $0.00-6.07 \%$ separately for age- 2 and $-3+$ birds, reflecting a cumulative removal of up to 1 million individuals across these age classes. The greater range of removals for age- 1 birds reflected the probability that older males would have migrated through the baiting areas prior to treatment with DRC-1339, thus leaving bait for females and younger males (Linz et al. 2002a). For the next 4 cull years, the maximum percentage removal for the 3 age classes changed relative to the age distribution of the precull population, which reflected reproduction and annual mortality subse- quent to the last cull. However, we maintained the same minimum percentage removal for each age class, and the absolute maximum removal also was maintained at 1 million birds each from within age-1, and age-2, and age- $3+$ classes combined. Subsequent to each cull, we expressed density compensation effects on adult survival as

$$
\begin{gathered}
{[(1-P) *(0.75-\text { age-specific survival })]} \\
+(\text { age-specific survival })
\end{gathered}
$$

where $P$ is the proportion of the original population size (i.e., 27 million birds) represented by birds surviving the cull and entering the breeding season, and 0.75 is the assumed maximum annual adult survival. Age-specific survival in the first cull year was 0.61 (Table 1), but increased as per Eq. 3 with each annual cull. After each cull, we postmultiplied the new projection matrix by a population vector representing the females that survived the cull and entered the breeding season, and then multiplied the product (which comprised hatch-year females and adult females) by 2 . Again we assumed a 1:1 sex ratio for adults and offspring. This procedure yielded the precull population for the next year (i.e., the population surviving through the week of $1 \mathrm{Apr}$, or the beginning of the annual cycle; Fig. 1). In addition, to reflect the population of red-wings potentially present within the sunflower region of North Dakota in the fall of a specific cull year, and therefore the effect of the culling scenario relative to a no-cull scenario (Fig. 1), we projected the time $t+1$ population to the week of 2 September (i.e., the population surviving through week 23 of a current model year).

Scenario II: Median Variable Annual Cull and No Density Compensation.-This 5-year simulation mimicked Scenario I, with the exception that adult survival was not adjusted to reflect densitydependent effects (i.e., adult survival was maintained at 0.61 ).

Scenario III: Maximum Annual Cull and Density Compensation.-Under this scenario, we removed 1 million age-1 birds and 1 million birds from age classes 2 and $3+$ combined. As in Scenario I, we assigned age-specific removals for age- 2 and $-3+$ birds based on $W_{X}$ for year 1 , and the age distribution of precull populations for each of the next 4 cull years.

Scenario IV: Maximum Annual Cull and No Density Compensation.-For this scenario, we mimicked Scenario III, with the exception that adult survival parameters within the projection matrix 
Table 2. Right $\left(W_{X} \text {, stable age distribution }\right)^{a}$ and left eigenvectors ( $V V_{X}$, reproductive values) of age-classified projection matrix $X$ for female red-winged blackbirds. Reproductive value (typically set to 1 for the youngest individuals) is a composite of the extent of future reproduction of a female of age $x$, the probability of surviving to realize that reproductive contribution, and the time required for the offspring to be produced.

\begin{tabular}{lcc}
\hline Age & $\begin{array}{c}\text { Stable } \\
\text { age distribution }\end{array}$ & $\begin{array}{c}\text { Reproductive value } \\
\text { (female fledglings/female of age } x \text { ) }\end{array}$ \\
\hline 1 & 0.39000 & 1.0 \\
2 & 0.23792 & 1.3 \\
$3+$ & 0.37208 & 1.4
\end{tabular}

a Equivalent to the stable age distribution for the population under the assumption of a 1:1 sex ratio.

were not adjusted to reflect density compensation (i.e., as in Scenario II).

\section{Economic Evaluation}

For each management alternative in the draft EIS that includes spring baiting, the proposed expenditures were $\$ 69,000$ annually over the 5 year program ( $\$ 345,000$ total) to cover salaries and benefits, facilities, equipment, and bait. We calculated discounted future value of the program expenditures (i.e., the net present value [PV]) as

$$
P V=(\$ 69,000)(1+i)^{-t}
$$

where $i$ was the discount rate (here, $7 \%$ annually) and $t$ was the year. Net PV is a simple equivalence relationship between sums of money payable at different points in time. Thus, for year 1, expenditures were not discounted, whereas the expenditures for year 2 were discounted to $\$ 64,485.98$. The PV for the 5-year program was $\$ 302,717$.

Peer et al. (2003) estimated the annual economic value of red-wing damage to sunflower crops, after taking into account sex-specific consumption and daily energy requirements, hull weight of the seeds, and market value of sunflower, as $\$ 0.09$ per male and $\$ 0.05$ per female (i.e., $\bar{x}=\$ 0.07)$. Homan et al. (2002) evaluated red-wing spring dispersal patterns and estimated that $82 \%$ of red-wings colormarked in eastern South Dakota during spring damaged sunflower crops during late summer (see also Linz et al. 2002a). We therefore calculated forgone damage to sunflower as a result of spring baiting as

$$
R_{t}^{*} 0.82 * \$ 0.07 *(0.96)
$$

where $R_{t}$ represents the baiting-related reduction in the model red-wing population beginning the week of 2 September of each cull year $t$ (i.e., model population beginning the week of $2 \mathrm{Sep}$ assuming no cull-model population at same time, but with cull effects). In addition, we assumed that $4 \%$ of the sunflower crop would not be harvested because of other losses (NASS 2000). Also, we discounted future foregone damage (i.e., calculated the PV in the same manner as program expenditures) by $7 \%$. The subsequent cost-benefit ratio was $\$ 302,717$ :forgone damage adjusted to PV.

\section{RESULTS}

The calibrated female matrix comprised $42.4 \%$ survival (for both male and female offspring) from fledging to just before age 1 . The stable age distribution (i.e., the proportion of the population at each age) comprised over $62 \%$ age- 1 and 2 individuals, and reproductive values increased through age $3+$ (Table 2 ). Our analysis revealed that the rate of population increase was most sensitive (i.e., exhibited the highest elasticity) to survival of age-3+ birds, followed by survival of age-1 birds (Fig. 2).

Under Scenario I, the mean median annual removal was $1,240,560(\mathrm{SE}=12,328)$ birds. Mean annual age-specific proportions removed were 7.6\% ( $\mathrm{SE}=0.31)$ of age-1 birds, $3.2 \%(\mathrm{SE}=0.13)$ of age- 2 birds, and $3.2 \%(\mathrm{SE}=0.11$ ) of age- $3+$ birds. The mean population size beginning the

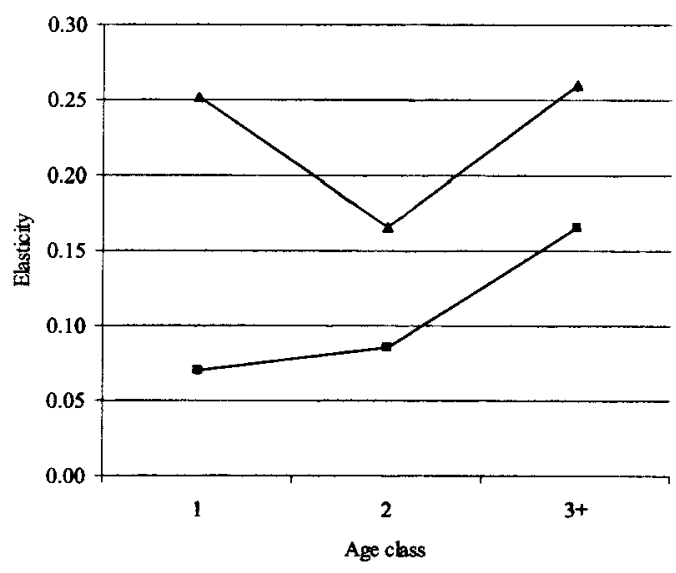

Fig. 2. Proportional change in the finite rate of increase $\lambda_{X}$ relative to proportional changes in the elements $x_{i j}$ of the projection matrix $X$ (i.e., the elasticity), an age-based matrix of a redwinged blackbird population exhibiting stable growth. The top line $(\Delta)$ represents elasticity in response to proportional changes in survival of birds from just before age 1 to just before age $2\left(S_{1}\right)$, just before age 2 to just before age $3\left(S_{2}\right)$, and just before age 3 on $\left(S_{3+}\right)$, while the bottom line $(\mathbb{\sigma})$ represents fertility of birds about to turn age $1\left(F_{1}\right)$, birds about to turn age $2\left(F_{2}\right)$, and birds about to turn age $3+\left(F_{3+}\right)$. 


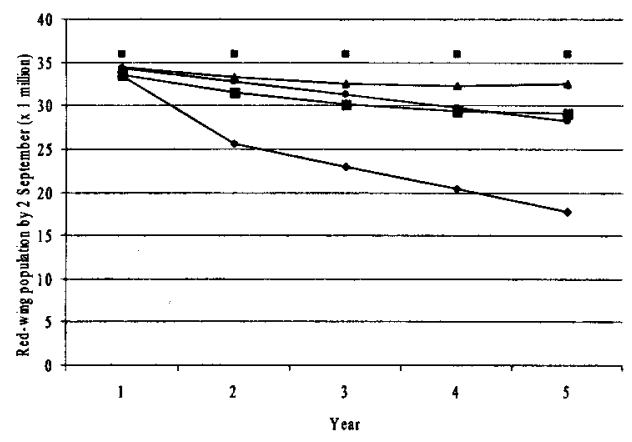

- N o- cull sceario $\rightarrow-$ Scenario I $\rightarrow$ Scenario II $\rightarrow-$ Scenario lll $\longrightarrow$ Sceario IV

Fig. 3. Four scenarios of the reduction of a stable red-winged blackbird population and projection of the population through week 23 of the model annual cycle (i.e., corresponding to the week of 2 Sep). Scenario I, Median Variable Annual Cull and Density Compensation: response to a mean (SE) median annual removal of $1,240,560(12,328)$ birds and density compensation effects on adult survival; Scenario II, Median Variable Annual Cull and No Density Compensation: response to the annual removal $1,231,620(28,811)$ birds and no density compensation effects on adult survival; Scenario III, Maximum Annual Cull and Density Compensation: response to the annual removal of 2 million birds and density compensation effects on adult survival; and Scenario IV, Maximum Annual Cull and No Density Compensation: response to the annual removal of 2 million birds and no density compensation effects on adult survival.

week of 2 September was $33.05(\mathrm{SE}=9.03)$ million birds, $91.9 \%$ of the no-cull scenario (Fig. 3). The intrinsic rate over the 5-year program (i.e., as of yr 6) was $-1.4 \%$ (Fig. 4). However, based on our assumptions regarding density compensation, adult survival by year 6 had increased to $66.64 \%$, with the population increasing at $6 \%$ annually. At the end of the 5-year period, PVadjusted forgone damage to sunflower crops was $\$ 688,821$, and the cost-benefit ratio was $1: 2.3$.

Under Scenario II, 1,231,620 (SE = 28,811) birds were removed annually. Mean annual age-specific proportions removed were $7.6 \%(\mathrm{SE}=0.31$ ) age-1 birds, $3.4 \%(\mathrm{SE}=0.31$ ) of age- 2 birds, and $3.3 \%(0.22)$ of age- $3+$ birds. By the week of 2 September, the mean population comprised 31.30 ( $\mathrm{SE}=2.42$ ) million birds, or $87.0 \%$ of no-cull scenario (Fig. 3). The population size at year 6 reflected an $r=-4.8 \%$ (Fig. 4). Again, we assumed that fertility and survival rates did not change; therefore, population growth from year 6 would remain stable. The PV-adjusted forgone damage to sunflower crops at the end of the 5 years was $\$ 1,078,743$; the cost-benefit ratio was 1:3.6.

For Scenario III, 2 million birds were removed annually and mean annual age-specific propor- tions removed were $10.8 \%(\mathrm{SE}=0.93)$ of age-1 birds, $6.4 \%$ ( $\mathrm{SE}=0.32$ ) of age-2 birds, and 6.6\% ( $\mathrm{SE}=0.36)$ of age-3+ birds. By the week of $2 \mathrm{Sep}-$ tember, $30.75(\mathrm{SE}=1.83)$ million birds were present $(85.5 \%$ of the no-cull scenario; Fig. 3). By year 6 , the population reflected an $r=-3.3 \%$ (Fig. 4). However, adult survival at year 6 was $69.42 \%$, and the expected annual rate of increase was $8.9 \%$. After 5 years of culling, PV-adjusted forgone damage was $\$ 1,225,838$, and the cost-benefit ratio was 1:4.

Scenario IV produced the most extreme population effects with the removal of 2 million birds annually and no density compensation effects on adult survival. Mean annual age-specific percentages removed were $13.2 \%$ ( $\mathrm{SE}=2.7$ ) of age-1 birds, $7.5 \%$ (SE $=1.3$ ) of age- 2 birds, and $8.6 \%$ $(\mathrm{SE}=1.8)$ of age- $3+$ birds. By the week of 2 September, $24.03(\mathrm{SE}=5.98)$ million birds were present, or $66.8 \%$ of the no-cull scenario (Fig. 3). The population at year 6 exhibited an $r=-14.0 \%$ (Fig. 4) and, given no compensatory response, would assume a stable population. The PV-adjusted forgone damages for the 5-year program were $\$ 2,766,651$, and the cost-benefit ratio was $1: 9$.

\section{DISCUSSION}

Predicting the effects of lethal control implemented away from the point of damage is inherently difficult (e.g., management efforts targeting the European starling [Sturnus vulgaris] in Belgium, Feare 1984; red-billed Quelea [Quelea quelea] in South Africa, Feare 1991; and woodpigeon [Columba palumbus] in the United Kingdom, Feare 1991). In the case of red-wings depredating ripening sunflower crops in the Great Plains, we constructed a biologically reasonable model of a red-wing population exhibiting stable growth. This model was useful in evaluating the efficacy of proposed spring baiting to reduce crop damage. We recognize that multiple variations of agespecific fertility and survival values within a matrix model might be calibrated to stable population growth, but not all would be realistic with respect to red-wing ecology.

For example, values for age-specific fledging success, a component of our fertility parameter, were comparable with values from marsh-nesting red-wings across North America (0.23-3.15 young fledged per female breeder), while our adult survival parameter slightly exceeded published values (40-60\%; Beletsky 1996). Had we reduced the parameter value for adult survival to approximately $50 \%$, the overall effect of the cull on sub- 


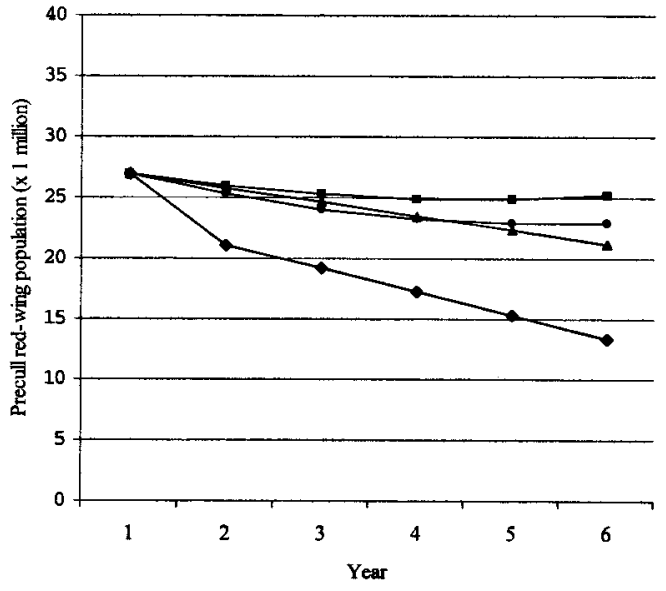

Scenario I $\leftarrow$ Scenario II $\rightarrow$ Scenario III $\bullet-$ Scenario IV

Fig. 4. Four scenarios of the reduction of a stable red-winged blackbird population and the subsequent projection of the population through the model annual cycle. Scenario /, Median Variable Annual Cull and Density Compensation: response to a mean (SE) median annual removal of $1,240,560(12,328)$ birds and density compensation effects on adult survival; Scenario /I, Median Variable Annual Cull and No Density Compensation: response to the annual removal $1,231,620$ $(28,811)$ birds and no density compensation effects on adult survival; Scenario III, Maximum Annual Cull and Density Compensation: response to the annual removal of 2 million birds and density compensation effects on adult survival; and Scenario IV, Maximum Annual Cull and No Density Compensation: response to the annual removal of 2 million birds and no density compensation effects on adult survival.

sequent model populations would be increased, as would economic justification for spring baiting. However, with the reduction in adult survival, the biological relevance of our model would be reduced. Specifically, the necessary increase in first-year survival to $50 \%$ (i.e., equal to adult survival) to slow the population decline is unrealistic and would not maintain the stable growth scenario. Generally, survival rates of hatch-year birds for any species are poorly understood, but for models of stable populations, an approach has been to solve for the juvenile survival value, given the adult parameters, that satisfies the stable rate (Henny et al. 1970).

Our analyses indicated that survival parameters, particularly survival of age- $3+$ birds (assuming a comparable value for females and males), outweighed effects of fertility on the annual rate of increase. However, the nearly equivalent elasticity value relative to survival of age- 1 birds indicates the importance of that age class to the annual rate of increase. Specifically, given the initial parameters (i.e., without compensation effects on survival) and equal proportionate changes to the vital rates, approximately $25.2 \%$ and $26.0 \%$ of any change in the annual rate of increase will be due to survival of age-1 and -3+ birds, respectively. Therefore, given our findings for the model population, the fate of age- 1 birds, in addition to age$3+$ birds, is likely critical to assessing potential effects of spring baiting with DRC-1339.

Across the 4 model scenarios, the mean annual percentage of age-1 birds culled was approximately twice that of older birds (percentages culled of age- 2 and $-3+$ birds were nearly equal). However, under operational conditions, selectively targeting age classes would be difficult. For example, because of timing of spring migration (see Beletsky 1996), older males likely will migrate through bait areas prior to use of treated baits (Linz et al. 2002a), thus leaving younger birds (i.e., age-1 birds) exposed to the treated baits (potential age-specific differences in timing of female migration are unknown). However, age-1 males composing the nonbreeding "floater" component of the population (Beletsky 1996, Sawin et al. 2003) that arrive at the breeding areas also will be available to usurp territories vacant as a result of baiting. Further, climate (e.g., snow cover or persistent rains) could cause birds of all age classes to delay migration and then move quickly through eastern South Dakota, possibly bypassing bait sites. Precipitation also would disrupt the timing of bait application as well as the effectiveness of baited sites because DRC-1339 is water soluble (U.S. Department of Agriculture Animal Plant Health Inspection Service specimen label, U.S. Environmental Registration Number 56228-30).

Our model is therefore simplistic relative to (1) age-specific mortality associated with spring baiting, (2) complications associated with quantifying the effects of immigration and emigration on the annual rate of increase, (3) variability associated with climatic and resource effects on population growth (Blackwell and Dolbeer 2001), (4) assumptions regarding the mean number of young fledged per female, (5) density-dependent effects on juvenile survival, and (6) the effects of the floater component relative to the number of birds removed via baiting and replacement of culled breeders. In addition, the plasticity of redwings relative to selection of breeding habit (Dyer et al. 1972) adds uncertainty to the effects of concurrent cattail management on the species' breeding dynamics. 


\section{MANAGEMENT IMPLICATIONS}

Unfortunately, long-term demographic data for red-wing populations in the Prairie Pothole Region of central North America-necessary to validate and refine this basic deterministic model-are not available. In our model, we assumed that culling mortality was additive, no replacement of breeders via immigration, and no density-dependent reproductive responses. Therefore, we contend that our results reflect worstcase scenarios with regard to the population effects of culling via spring baiting integrated with current nonlethal management efforts. Further, our population projection for the second week of September is a biologically realistic representation of the red-wing population potentially available to depredate sunflower crops and thus a reasonable approximation for the economic evaluation of culling.

Importantly, instances where data are limited should not deter evaluation of management scenarios; no evaluation of management scenarios is comparable with making a management decision. Therefore, in such cases a deterministic projection matrix provides a dynamic method for comparison of potential relative effects of population parameters within local or regional populations, as well as later refinement to include stochastic properties (see Beissinger and Westphal 1998, Reed et al. 1998). For example, the need to evaluate potential management strategies-despite inadequate population data-has driven similar approaches involving management of endangered species (e.g., Crouse et al. 1987, Crowder et al. 1994, Kareiva et al. 2000), wildlife damage (e.g., Bosch et al. 2000, Blackwell et al. 2002), and waterfowl populations (e.g., Williams 1989, Williams and Nichols 1990, Johnson and Williams 1999).

Under our assumptions, a cull of 2 million redwings annually (Scenarios III and IV), achievable with ideal climatic conditions and logistics ( $P$. Mastrangelo, WS State Director-North Dakota, personal communication), could potentially provide $\$ 923,121$ to $\$ 2,463,934$ in net benefits to sunflower growers. However, given the possibility of weather-related migration delays and the uncertainty in the degree of compensation in survival resulting from culling, we suggest that Scenarios I and II provide the best range of estimates for the potential population response to culling via spring baiting. Specifically, these simulations indicated that our model population, following the fifth year of culling, would comprise on average between 21.2 and 25.2 million birds, or between 78.5 and $93.2 \%$ of the original 27 million birds. Subsequent net benefits to sunflower growers from spring baiting red-wings ranged from $\$ 386,103$ to $\$ 776,026$ for the 5 years.

In addition, realized benefits to sunflower growers from lethal control of red-wings via spring baiting can also result in indirect economic benefits to associated industries and local economies. However, realized benefits to sunflower growers might also fall short of the most likely range of model predictions when considering potential indirect costs. For example, we do not know how public opinion concerning spring baiting of redwings would affect the marketability of sunflower products. Therefore, recognizing the potential variability in the effectiveness of the cull combined with direct costs and the possibility of contrasting indirect economic effects, we contend that only a marginal economic justification exists for spring baiting of red-winged blackbirds, given current nonlethal management efforts. However, the economic justification for spring baiting as a component of an integrated program involving a $0.3 \%$ increase in annual herbicide applications to cattail-dominated wetlands remains unclear.

\section{ACKNOWLEDGMENTS}

Financial support for this study was provided by the USDA's National Wildlife Research Center and Office of Policy and Program Development, Policy Analysis and Development. We thank T. Hall, D. Hayes, and P. Mastrangelo for their advice relative to the operational perspective of a baiting program. We also thank J. Cummings, $\mathrm{T}$. Hall, D. Hayes, P. Mastrangelo, and 3 anonymous reviewers for comments on earlier drafts of this manuscript.

\section{LITERATURE CITED}

BANGSund, D. A., AND F. L. LeIsTRITz. 1995. Economic contribution of the United States sunflower industry. Agricultural Economics Report 327. Department of Agricultural Economics, North Dakota State University, Experiment Station, Fargo, North Dakota, USA. BEISSINGER, S. R., AND M. I. WESTPHAL. 1998. On the use of demographic models of population viability in endangered species management. Journal of Wildlife Management 62:821-841.

Beletskx, L. 1996. The red-winged blackbird. The biology of a strongly polygynous songbird. Academic Press, London, United Kingdom.

Besser, J. F., J. W. DeGrazio, And J. L. Guarino. 1983. Seasonal movements of red-winged blackbirds banded in Brown County, South Dakota 1961-1971. North American Bird Bander 8:140-143.

BIACKWELL, B. F., AND R. A. DOLBEER. 2001. Decline of the red-winged blackbird population in Ohio corre- 
lated to changes in agriculture (1965-1996). Journal of Wildlife Management 65:661-667.

, M. A. Stapanian, and D. V. C. Weseloh. 2002. Dynamics of the double-crested cormorant population on Lake Ontario. Wildlife Society Bulletin 30:345-353.

Bosch, M., D. Oro, F. J. Cantos, And M. Zabala. 2000. Short-term effects of culling on the ecology and population dynamics of the yellow-legged gull. Journal of Applied Ecology 37:369-385.

CASWELL, H. 1989. Matrix population models. Sinauer Associates, Sunderland, Massachusetts, USA.

- , R. NAIMAN, AND R. MORIN. 1984. Evaluating the consequences of reproduction in complex salmonid life cycles. Aquaculture 43:123-143.

CAUGHLEX, G. 1977. Analysis of vertebrate populations. John Wiley \& Sons, Brisbane, Australia.

Crouse, D. T., L. B. Crowder, AND H. Caswell. 1987. A stage-based population model for loggerhead sea turtles and implications for conservation. Ecology 68:1412-1423.

Crowder, L. B., D. T. Crouse, S. S. Heppell, and T. H. MARTIN. 1994. Predicting the impact of turtle excluder devices on loggerhead sea turtle populations. Ecological Applications 4:437-445.

de Kroon, H., A. Plaisier, J. van Groenendael, and H. CASWELL. 1986. Elasticity: the relative contribution of demographic parameters to population growth rate. Ecology 67:1427-1431.

DOLBEER, R. A. 1978. Movement and migration patterns of red-winged blackbirds: a continental overview. Bird-Banding 49:17-34.

1982. Migration patterns for age and sex classes of blackbirds and starlings. Journal of Field Ornithology 53:28-46.

Dyer, M. I., D. B. Siniff, S. G. Curtis, And J. S. WebB. 1972. Distribution of red-winged blackbird (Agelaius phoeniceus L.) populations in the Lake Erie region of the United States and Canada. Pages 213-234 in S. C. Kendeigh and J. Pinowski Warzawa, editors. Productivity, population dynamics and systematics of granivorous birds. Proceedings of the general meeting of the working group on granivorous birds, IBP, PT section. The Hague, The Netherlands.

Eisemann, J. D., G. M. Linz, AND J. J. Johnston. 2001. Non-target hazard assessment of using DRC-1339 avicide to manage blackbirds in sunflower. Pages 197-211 in J. J. Johnston, editor. Pesticides and wildlife. American Chemical Society, Washington, D.C., USA.

FEARE, C., 1984. The starling. Oxford University Press, London, United Kingdom.

1991. Control of bird pest populations. Pages 463-478 in C. M. Perrins, J.-D. Lebreton, and G. J. M. Hirons, editors. Bird population studies (relevance to conservation and management). Oxford University Press, New York, New York, USA.

Henny, C. J., W. S. Overton, AND H. M. Wright. 1970. Determining parameters for populations by using structural models. Journal of Wildlife Management 34:690-703.

Homan, H. J., G. M. LinZ, R. C. Carlson, and W. J. Bleier. 2003. Spring distribution of ring-necked pheasants (Phasianus colchicus) following cattail reduction with glyphosate herbicide. Wildlife Research 30:1-8.

, R. M. ENGEMAN, AND L. B. PENRY. 2002.

Spring dispersal patterns of red-winged blackbirds
(Agelaius phoeniceus) staging in east-central South Dakota. Proceedings of the Sunflower Research Workshop 24:155-158.

Hothem, R. L., R. W. DeHaven, and S. D. Fairaizl. 1988. Bird damage to sunflower in North Dakota, South Dakota, and Minnesota, 1979-1981. U.S. Fish and Wildlife Service Technical Report 15. U.S. Government Printing Office, Washington, D.C., USA.

Johnson, F., AND K. Williams. 1999. Protocol and practice in the adaptive management of waterfowl harvests. Conservation Ecology 3:8. [http://www.consecol.org/vol3/iss1/art8].

KANTRUD, H. A. 1986. Effects of vegetation manipulation on breeding waterfowl in prairie wetlands: a literature review. U.S. Fish and Wildlife Service Technical Report 3. U.S. Government Printing Office, Washington, D.C., USA.

Kareiva, P., M. Marvier, AND M. McClune. 2000. Recovery and management options for spring/summer chinook salmon in the Columbia River Basin. Science 290:977-979.

Knittle, C. E., G. M. Linz, B. E. Johns, J. L. Cummings, J. E. DAVIS, JR., AND M. M. JAEGER. 1987. Dispersal of male red-winged blackbirds from two spring roosts in central North America. Journal of Field Ornithology 58:490-498.

LeITCH, J. A., G. M. Linz, AND J. F. BALTEzore. 1997. Economics of cattail (Typha spp.) control to reduce blackbird damage to sunflower. Agriculture, Ecosystems and Environment 65:141-149.

LinZ, G. M., A. E. BARRAS, R. A. SAWIN, H. J. HOMAN, AND W. J. BlEIER. 2002a. Spring migration phenology and habitat use of red-winged blackbirds in eastern South Dakota. Proceedings of the Vertebrate Pest Conference 20:97-102.

, D. L. Bergman, D. C. Blixt, ANd W. J. Bleier. 1994. Response of black terns (Chlidonias niger) to glyphosate-induced habitat alterations on wetlands. Colonial Waterbirds 17:160-167.

, AND D. C. BIIXT. 1997. Black terns benefit from cattail management in the northern Great Plains. Colonial Waterbirds 20:617-621.

, D. L. Bergman, AND W. J. Bleier. $1996 a$. Response of red-winged blackbirds, yellow-headed blackbirds and marsh wrens to glyphosate-induced alterations in cattail density. Journal of Field Ornithology 67:167-176.

$\longrightarrow,-1$, $\longrightarrow$, and - 1996b. Response of ducks to glyphosate-induced habitat alterations in wetlands. Wetlands 16:38-44.

, $\longrightarrow$, AND C. MCMURL. 1997. Response of American coots and soras to herbicide-induced vegetation changes in wetlands. Journal of Field Ornithology 68:450-457.

- AND J. J. HANZEL. 1997. Birds and sunflower. Pages 381-394 in A. Schneider, editor. Sunflower science and technology. American Society of Agronomy, Madison, Wisconsin, USA.

- M. J. KenYon, H. J. Homan, and W. J. Bleier. 2002b. Avian use of rice-baited corn stubble in eastcentral South Dakota. International Biodeterioration and Biodegredation 49:179-184.

- L. J. Linz, J. M. Thompson, and W. J. Bleier. 1993. Using geographic variation to predict breeding locales of migrating red-winged blackbirds. Prairie Naturalist 25:127-133. 
D. L. VAKOCH, J. F. CASSEL, AND R. B. CARLSON. 1984. Food of red-winged blackbird (Agelaius phoeniceus) in sunflower fields and corn fields. Canadian Field-Naturalist 93:38-44.

MCDONALD, D. B., AND H. CASWELL. 1993. Matrix methods for avian demography. Pages 139-185 in D. M. Power, editor. Current ornithology. Volume 10. Plenum Press, New York, New York, USA.

NASS. National Agricultural Statistics Service. 1999. NASS, Agricultural Statistics Board, U.S. Department of Agriculture, Washington, D.C., USA.

2000. NASS, Agricultural Statistics Board, U.S. Department of Agriculture, Washington, D.C., USA.

PeER, B. D., H. J. Homan, G. M. Linz, AND W. J. Bleier. 2003. Impact of blackbird damage to sunflower: bioenergetic and economic models. Ecological Applications 13:248-256.

ReED, J. M., D. D. MurPhy, AND P. F. BRussard. 1998. The efficacy of population viability analysis. Wildlife Society Bulletin 26:244-251.

SaUER, J. R., J. E. Hines, and J. Fallon. 2001. The North American Breeding Bird Survey, results and analysis 1966-2000. Version 2001.2. U.S. Geological Survey, Patuxent Wildlife Research Center, Laurel, Maryland, USA.

SAWIN, R. S., G. M. LINZ, R. L. WIMBERLY, M. W. LUTMAN, AND W. J. BLEIER. 2003. Estimating the number of nonbreeding male red-winged blackbirds in a population in central North Dakota. In G. M. Linz, editor. Management of North American blackbirds. National Wildlife Research Center. In press.

SEARCY, W. A., AND K. YASUKAWA. 1981. Sexual size dimorphism and survival of male and female blackbirds (Icteridae). Auk 98:457-465.

STEHN, R. A. 1989a. Reproductive rate of red-winged blackbirds. Bird Section Research Report 430. U.S. Department of Agriculture, Animal and Plant Health Inspection Service, Wildlife Services, Denver Wildlife Research Center, Ohio Field Station.

. 1989b. Adult survival rate of red-winged blackbirds. Bird Section Research Report 431. U.S. Department of Agriculture, Animal and Plant Health Inspection Service, Wildlife Services, Denver Wildlife Research Center, Ohio Field Station.

. 1989c. Population ecology and management strategies for red-winged blackbirds. Bird Section Research Report 432. U.S. Department of Agriculture, Animal and Plant Health Inspection Service, Wildlife Services, Denver Wildlife Research Center, Ohio Field Station.

USDA. U.S. DEPARTMENT OF AGRICUlTURE. 2000. National Sunflower Association Sunstats 1999. [http://www.sunflowernsa.com/producers/mark/sunstats_99.html].

2001. Protection of sunflowers from red-winged blackbirds in North Dakota, South Dakota, and Minnesota; request for public involvement. Animal and Plant Health Inspection Service, Office of Policy and Program Development, Regulatory Analysis and Development, Docket No. 01-013-1. Federal Register 66:63356-63358.

Williams, B. K. 1989. Review of dynamic optimization methods in renewable natural resource management. Natural Resource Modeling 3:137-216.

- AND J. D. Nichols. 1990. Modeling and the management of migratory birds. Natural Resource Modeling 4:273-311.

Received 11 July 2002.

Accepted 7 July 2003.

Associate Editor: Flaspohler. 